\title{
STRATEGIES OF EFFECTIVE DEVELOPMENT OF PARTICIPANTS THE INNOVATIVE PROCESS
}

\section{Dovbenko Viacheslav ${ }^{1}$}

DOI: http://dx.doi.org/10.30525/978-9934-571-28-2_11

\begin{abstract}
In the paper, the process of developing strategies for the effective development of participants in the innovation process in the conditions of the crisis is studied in order to quickly overcome the negative trends in the economy. The purpose of this paper is to summarise the existing opinions and present new approaches in forming the strategies of efficient development of innovation process participants. The method of extended study allows revealing the main causes, opportunities and threads on the way of innovation activity enhancements in Ukrainian economy. The analysis the factors of influence on innovation activity revealed insufficient attention to this problem from the state, lack of purposeful actions aimed at correcting the situation with chronic underfunding of science and especially the sphere of research and development. Methodology. The survey is based on a systematic approach to the consideration the processes of forming a strategy of effective development the participants of innovation process and implementation this strategy despite the economic crisis. For this purpose, methods of induction and deduction, comprehensive analysis of interdependencies of individual components of the potential of innovation development are used. In addition the modeling of interaction the participants in innovation process was actualized. The paper at first to identify the general causes and phenomena with a gradual transition to the consideration of specific problems that hinder the achievement of the assigned goals for the activation the processes of knowledge and technology transfer and the timely commercialization the $R \& D$ results. The purpose of the research is the theoretical questions of the formation a strategy of the effective development the innovation process participants to investigate, the condition of innovation ecosystem to analyze, the prospects a mechanism of commercializing the results of $R \& D$ to create. Practical implications. The open
\end{abstract}

${ }^{1}$ Candidate of Economic Sciences,

Associate Professor at Department of Business Economics and Investment, Lviv Polytechnic National University, Ukraine 


\section{Strategies of effective development of participants the innovative process}

innovation strategy must enable increasing cooperation among different partners and their R\&D activities by greater use of common know-how and resources. Innovation strategy will require a change in the company which should concern to the level of relationship with partners outside, as well as with employees inside the company. The role of innovation ecosystem in economic development in the current circumstances is growing significantly. A favourable business environment allows efficiently combine the interests of the company and its partners to determine the relationship of the parties, and thus ways to achieve the goals of development. Innovation strategy is significantly affected by innovation potential and management, lateral thinking, innovation, investment climate and organizational structure. For increasing the innovation activity it is necessary the established cooperation among different partners involved in innovation process. Conclusion. Importantly for every participants of innovation process is the right selection the individual components of the mechanism of innovation development and creation the conditions for optimal interaction. In this case a synergy effect will ensure a more efficient use of the resource potential and allow acquiring an additional cumulative effect.

\section{Introduction}

In the economic crises conditions, it is important to adopt qualitatively new strategic decisions regarding the renewal of existing potential of country to better utilize opportunities for economic and social development. The solution of this problem is impossible without reorienting the economy to the innovative way of development. These tasks are extremely actual and urgent about time of their solution because Ukraine has become significantly behind its neighbors as well in terms of development rates and as in terms of living standards.

The purpose of the research is to reasoning the theoretical questions of the formation a strategy for the effective development of innovation process participants, the analysis of the condition the innovation ecosystem, the prospects for creating a mechanism for promoting innovation activities and the processes of commercializing the results of R\&D.

The tasks of this paper is to investigate the existing condition of innovation activity in the economy, to analyze approaches to the shaping an innovation strategy that provides for the effective development of the innovation process participants, the possibility of improving the innovation ecosystem 


\section{Dovbenko Viacheslav}

and the formation a mechanism to facilitate the transfer of knowledge and technology using of business-models and modern tools for the implementation of innovative projects.

The basis of the methodology of this study is the systematic approach to the consideration the processes of forming an innovation strategy and its implementation in the context of economic crisis. For this purpose, methods of induction and deduction, analysis of interdependencies of individual components of the potential of innovation development and modeling the interaction of participants in innovation process are used. The material is presented in a logical sequence in order to identify first the general causes and phenomena with a gradual transition to the consideration of specific problems that hinder the achievement of the goals set for the activation the processes of knowledge and technology transfer and the timely commercialization of the results of the R\&D.

The companies must have a good developed strategy for the purpose of its effective development. In modern conditions, this strategy must contain an innovative strategy as its core. However, in the world of new technologies, the requirement for close cooperation between the parties is becoming more and more obvious, as even the large companies experiencing difficulties in providing ever-increasing volumes of $R \& D$ that can maintain a high level of competitiveness. These reasons are associated with growing interdisciplinarity $\mathrm{R} \& \mathrm{D}$ and the need for timely commercialization of their results. In modern conditions, the bases of economic development are innovative factors, which replaced the factors of additional attraction of resources and their effective use. Of course, the recent last listed factors have not completely lost their role, especially those that maximally take into account the possibilities of efficient use of resources.

The state of innovation activity in Ukraine is difficult to consider satisfactory. Despite the presence of significant scientific potential and the experience of creating technologically complex products, the country loses its position in the markets of high-tech goods and services $[1, p .8]$. Currently the development of innovation networks in Ukraine can be characterized as fragmentary. At the national and regional level are deployed a number of network organizations and its elements (innovation centres, technology transfer departments etc) [1, p. 183].

The conditions of economic development of enterprises in Ukraine are at the moment adverse and do not encourage to invest in innovative projects. The 


\section{Strategies of effective development of participants the innovative process}

share of R\&D outlay in GDP over the past decades has been steadily declining and in 2016 it was only $0.48 \%$ while in developed countries it is several times higher. Even such neighbouring countries as Hungary, Poland, Romania and Slovakia, today have much higher levels of outlay for science support in GDP.

Generally, innovative activity, like no other, is associated with high risk. However, with the right policy of supporting the participants of the innovation process by the state, investments in innovation activities provide a much higher level of return than other types of activities. To do this, it is necessary, taking into account the best world experience, to create a modern innovative infrastructure that helps at various stages from idea to commercialization of R\&D results to adequately assess and support the efforts of stakeholders in the process of development and implementation of various innovative projects. Possibilities of establishing effective interaction of the participants of the innovation process can be disclosed only under the condition of a branched network of technology transfer, in where each given idea has a chance to be considered and supported.

The business development strategies require attention to its implementation in terms of the need to consider all of the significant factors of influence on the enterprise. Each concrete new idea may be borne from the subjective mind of an innovator. Therefore, in some cases, forecasts regarding the amount of necessary funds, timing of implementation and expected results of a particular innovation project can significantly deviate from the original proposed option. These risks should be taken into account and covered with the expense of pre-allocated funds and distributed in a limited set of initially selected and approved ideas and projects.

In the current conditions, it becomes increasingly clear that, in a globalized world, social factors are becoming more and more important, as at the same time the barriers to the movement of not only goods but also labour and capital have decreased significantly and this requires the application of new approaches to managing the development of economic relations at different levels. Many industries were transferred to markets with cheap labour. Increasingly important especially in the field of innovation acquire the phenomenon of transferring a number of works to outsourcing. This requires special attention to the issues of interaction of the participants of the innovation process on the basis of transparency of the conclusion of agreements using tender (competitive) procedures, mutual trust and responsibility for fulfilling their commitments. 


\section{Dovbenko Viacheslav}

At present it is growing new type of relationship in the field of innovation on the principles of open innovation and triple helix model. This helps to bring the "fresh blood" into the innovation process by expanding the range of potential participants, reducing the cost to providing $R \& D$, accelerating the processes of commercialization and the launch of new products on the market. It also provides a social effect by creating conditions for discovering the creative potential of inventors and setting up better interactions with the consumers at different stages of the innovation process.

The process of the strategy formation begins with the goals for the business's product innovation effort and a clear understanding of how these innovation goals tie into broader business goals. An important facet of an innovation strategy is resource commitment and allocation. Appropriate environments for businesses, industry, universities and researchers, enabling innovation and delivering impact from research investment provide research and innovation campuses. Open business strategy should create a complementary synergic business environment in where external partners, customers or other stakeholders are more deeply involved in an innovation process. The open innovation strategy provides a close cooperation among different partners and their R\&D activities by greater use of common know-how and resources.

The activation of innovation activity is impossible outside the investment component, which provides innovative development with an appropriate level of financial support. Access to academic networks allows the identification of competences for future collaboration or recruitment and offers an arena to interact with competitors and customers.

Modern tools that improve the conditions for the implementation of innovative strategies of companies are Design Thinking and Agile Methodology. Design Thinking is the most effective way to understand a customer's needs. The derivative of the Agile is Scrum. It is an effective, smart and perfect example of how maximum input equals maximum output. Design Thinking and Agile both offer unique advantages for innovation, productivity and profit making.

There is a high probability of emerging competitiveness in the market through the introduction of new business-models. In the world of practice, there are plenty of examples of companies that have successfully entered the market using the new business-models (Southwest, Amazon, FedEx, Wal-Mart, McDonald's, IKEA, Enterprise, eBay, Priceline, Dell Comput- 


\section{Strategies of effective development of participants the innovative process}

ers, Starbucks, Skype, Groupon, etc.). With the onset of the information and communication technology era, appeared innovation business models developed by companies such as Microsoft, Intel, Dell-Computer, eBay and Amazon.com, IKEA, Google, Apple. These companies today also offer innovative approaches to offering similar products and services, besides continuously improving them. Thus, emerging appeared innovation business models are becoming a powerful competitive tools [2, p. 51].

The solution to the strategic tasks of development is based on clusters, which provide the basis for intensifying the processes of generating ideas, exchanging information and expanding the opportunities for the practical use of excellence and optimal combination of different stages the innovation cycle. The activities of innovative clusters create a favourable environment for successful implementation of innovative projects and achievement of the set goals of the development of some regions.

\section{Choice of innovation development strategy}

In order to ensure a high level of competitiveness in the market, any enterprise is required to form its own development strategy, which should become a means to achieve the set future goals of the activity.

Innovation strategy $\left(\mathrm{I}_{\mathrm{s}}\right)$ is significantly affected by five basic (core) elements. It can be entered in the form of the functions of five variables that affect the implementation and realization of innovative strategies [3, p. 820]:

$$
I_{s}=f\left(I_{m}, I_{p s}, L_{m}, P_{k}, O_{s}\right)
$$

where $I_{m}$ - innovation management, $I_{p s}$ - innovative potential of strategy, $\mathrm{L}_{\mathrm{m}}$ - lateral thinking, $\mathrm{P}_{\mathrm{k}}$ - pro-innovation climate and $\mathrm{O}_{\mathrm{s}}-$ organizational structure.

Before the creation of innovative strategies the enterprise should, an audit of situation is required. An audit includes identification and analysis of human potential, competitors, partners, customers and business needs to create innovations.

For analysis of the initial position of a company may be based on broad methodological apparatus of strategic management: the forecasting method (expert, simulation, projection, and forecast type of scenarios), conceptually methodological tools (SWOT analysis, BCG matrix, matrix product technology, map of project risks, SPACE analysis STEEP analysis, Porter analysis etc.) and innovative graphs (method S-curves, J-curve method, the method of "gap analysis") [3, p. 822]. 
Analysis of internal environment includes the creation of innovation capacity, innovation potential mapping, identifying the current level of use of the innovation capacity of innovation and specification requirements. Innovation capacity is formed by the sum of knowledge, experience, resources, assets and managerial capabilities and skills in business available, or is able to obtain in due time.

An enterprise can make decisions about choosing its development strategy using the matrix of the Boston Consulting Group (BKG). For the assessment of their products, they are divided into four groups by the indicators of market share, market growth rates, risk and profitability. The use of the BCG matrix for selecting enterprise development strategies is shown in Fig. 1.

\begin{tabular}{|l|l|l|l|l|}
\hline Stages of the life cycle & Origin & Development & Maturity & Decline \\
\hline Market share & Low & Moderate & High & Moderate \\
\hline Market growth rates & Low & High & Moderate & Low \\
\hline Risk & Very high & High & Moderate & Low \\
\hline Profitability & Low & High & Moderate & Low \\
\hline Total contribution & Very low & Moderate & High & Low \\
\hline \multicolumn{3}{|c|}{$\begin{array}{c}\text { Question Marks } \\
\text { Market Stars }\end{array}$} & Cash Cows & Dogs \\
\hline \multirow{2}{*}{$\begin{array}{c}\text { Share Stars } \\
\text { Low }\end{array}$} & \multicolumn{2}{|c|}{ Cash Cows } \\
\cline { 2 - 5 } & \multicolumn{2}{c}{ Digh Marks } \\
\cline { 2 - 5 }
\end{tabular}

\section{Fig. 1. Application of the BCG matrix for choosing development strategy}

Source: Composed by the author on the basis of the paper [4, p. 237-238]

The enumeration of upper level strategic aims can be formed for the enterprise's innovation development strategy as a progressive, zero and regressive innovation development. Three types of innovation strategies correspond to these aims: advance strategy, defense strategy, expectation strategy [5, p. 77].

The next level of strategic aim formation is based on the study of those economic advantages which are appealed to while realizing the first level aims. Thus, the major component of the second level classification is "com- 
petitiveness". The main features of the competition are: price, quality, opportunities, novelty of manufactured products, technologies which are used, and markets which are supplied, that include, in particular, improving the quality $(\mathrm{Q})$; reduction of costs $(\mathrm{C})$ and prices $(\mathrm{P})$; increasing of the output of products $(\mathrm{O})$; development of the market for production $(\mathrm{M})$; development of the manufacture of new for the enterprise products $(\mathrm{Np})$; development of the radical product innovations and technologies (Pp).

The main subtypes of innovation strategies for increasing competitiveness in certain areas are given in Tab. 1.

The strategy of innovation development of the enterprise should logically combine different types of the given above strategic development directions.

Table 1

\section{The main types of products reproduction in terms of innovation strategies}

\begin{tabular}{|l|l|l|}
\hline \multicolumn{1}{|c|}{$\begin{array}{c}\text { Subtype } \\
\text { of strategy }\end{array}$} & $\begin{array}{l}\text { The main types of innovations/ } \\
\text { Combination of goals of competitive } \\
\text { strategies }\end{array}$ & Source of innovations \\
\hline Active-advance & $\begin{array}{l}\text { Radical process and product } \\
\text { innovations. Development of new } \\
\text { markets. Improving production } \\
\text { innovations of second generation }\end{array}$ & $\begin{array}{l}\text { Available scientific and } \\
\text { technical achievements }\end{array}$ \\
\hline Passive advance & $\begin{array}{l}\text { Improving and ordinary innovation } \\
\text { in the production of the second } \\
\text { generation }\end{array}$ & $\begin{array}{l}\text { Available scientific and } \\
\text { technical achievements }\end{array}$ \\
\hline Opportunistic & $\begin{array}{l}\text { Improving production innovation, } \\
\text { differentiation of highly profitable } \\
\text { production of the second generation }\end{array}$ & $\begin{array}{l}\text { Available scientific and } \\
\text { technical achievements }\end{array}$ \\
\hline Protective & $\begin{array}{l}\text { Rationalization of production. } \\
\text { Improving and ordinary innovations } \\
\text { of new products }\end{array}$ & $\begin{array}{l}\text { Legally protected } \\
\text { industrial property objects }\end{array}$ \\
\hline Simulating & $\begin{array}{l}\text { Purchasing license-based production } \\
\text { technologies }\end{array}$ & Licenses for technologies \\
\hline Traditional & $\begin{array}{l}\text { Improving of production of long- } \\
\text { lasting, stable demand. Improving of } \\
\text { technology, product quality, marketing } \\
\text { system }\end{array}$ & $\begin{array}{l}\text { Available scientific and } \\
\text { technical achievements }\end{array}$ \\
\hline $\begin{array}{l}\text { Search for own } \\
\text { niche }\end{array}$ & $\begin{array}{l}\text { Ordinary innovations, radical } \\
\text { innovations are possible }\end{array}$ & Own R\&D \\
\hline
\end{tabular}

Source: Composed by the author on the basis of the paper [5, p. 78] 
The development of an innovation strategy involves a number of stages:

- forecasting promising development directions of industry and market in which the enterprise operates;

- identification of priority areas for innovative development;

- elaboration of an innovative development strategy.

At the stage of elaboration is chosen the type of innovation development strategy. The types of innovation strategy include:

- offensive strategy, which involves creation and active implementation of innovations (if the company has strong scientific, research and design departments);

- defensive strategy, which involves improving product and technology of its production, promotion methods etc.;

- simulation strategy, which involves the acquisition of licenses or patents and technical preparation for innovation production;

- dependent strategy adhered by enterprises that manufacture components for innovative products to other businesses (a subtype of offensive or defensive);

- traditional strategy, involving only minor product improvements (company manufactures unique products or technologies);

- niche strategy (used by companies manufacturing innovative products that address specific needs of small groups of consumers);

- licensing strategy, which involves the search of partners for implementation or selling innovations, patents, licenses etc. (it is typical for small companies);

- mixed strategy (as a combination of different strategies).

The strategy type choice based for awareness of the stages of innovative and life cycle of new products. The selection pattern for the choice of innovation strategy is presented in Table 2 .

Companies can choose different forms of how to open their innovation strategies, such as partnerships with external parties (business alliances, joint ventures, joint R\&D), acquisitions, contractual R\&D, purchasing of patents, licensing, etc. In addition to these common forms, an open innovation strategy can be realized through spin-offs or venture capital investment funds too. The open innovation strategy must enable increasing cooperation among different partners and their R\&D activities by greater use of common know-how and resources. Generally, every new member of a group should enhance the synergy of openness in two ways: 
Types innovation strategies and business depending on stage of innovative cycle

\begin{tabular}{|c|c|c|c|c|c|c|c|c|c|}
\hline \multirow{3}{*}{$\begin{array}{c}\text { Strategy } \\
\text { type }\end{array}$} & \multirow{3}{*}{$\begin{array}{c}\text { Innovative } \\
\text { business } \\
\text { type }\end{array}$} & \multicolumn{6}{|c|}{ Stages of innovative cycle } & & \\
\hline & & \multirow[b]{2}{*}{ 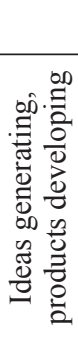 } & \multirow[b]{2}{*}{ 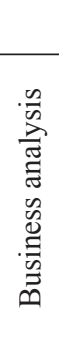 } & \multirow[b]{2}{*}{ 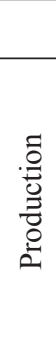 } & \multirow[b]{2}{*}{ 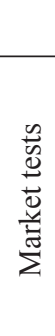 } & \multicolumn{4}{|c|}{ Stages of life cycle } \\
\hline & & & & & & 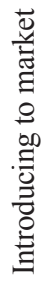 & 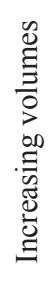 & 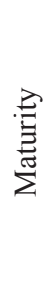 & 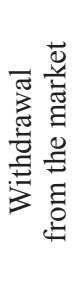 \\
\hline Licensing & \multirow{3}{*}{ Venture } & + & & & & & & & \\
\hline Simulating & & & + & + & + & & & & \\
\hline Licensing & & + & + & + & + & & & & \\
\hline Simulating & Explerent & & & & & + & & & \\
\hline Niche & Patient & & & & & & + & & \\
\hline $\begin{array}{l}\text { Traditional } \\
\text { defensive }\end{array}$ & Violent & & & & & & & + & \\
\hline Niche & Commutant & & & & & & & & + \\
\hline Simulating & \multirow{3}{*}{ Combined } & & + & + & + & + & & & \\
\hline Offensive & & + & + & + & + & + & & & \\
\hline Defensive & & & & & & & + & + & + \\
\hline
\end{tabular}

Source: Composed by the author on the basis of the paper [6, p. 177]

1) contribute to the synergic value creation by its own resources and know-how to a higher level of effectiveness and by avoiding sub-optimal outcomes/biases of the cooperation;

2) promote to improving the social climate [7].

The degree of openness of an innovation strategy differs depending on factors such as importance of technology, autonomy of new organization, risk taking, time for new/ innovative technology adoption, enablement of the main business strategy, dissimilarity in technologies, products or markets, engagement of people cooperating, or complexity of solutions. Based on these factors, in addition to the classical closed innovation strategy and the fully open innovation strategy, it does distinguish an advanced innovation strategy and a limited open innovation strategy [8, p. 19]. 


\section{Dovbenko Viacheslav}

Innovation strategy will require a change in the organizational structure of the company. Successful innovation strategy helps in providing of information to staff about where the company is going with innovations, what motivates employees, what is the meaning of their work.

\section{The role of innovation ecosystem in economic development}

Implementation of the innovation strategy of any subject of management depends on the conditions of the innovation ecosystem. It is important to create the necessary conditions for successful implementation the development strategies of the participants the innovation process, including the availability of developed innovation infrastructure, the modern legislative field, state support, relations of responsible attitude to fulfil their commitments and trust between partners.

We use the term "innovation ecosystem" to refer to the inter-organizational, political, economic, environmental and technological systems of innovation through which a milieu conducive to business growth is catalyzed, sustained and supported. An innovation ecosystem is a network of relationships through which information and talent flow through systems of sustained value co-creation. The systems approach has been used to describe the multifaceted nature of innovation at various levels - national, regional, technological, and sectors - and to describe the processes by which research capabilities build knowledge, and then transfer the knowledge to support business development in the context of the Triple Helix of business, government and academic interaction [9].

Innovation ecosystem is viewed then as a dynamic system, characterized by localized interactions among a huge amount and diversity of agents - universities, business, public institutions, society, resources, etc. Their interaction is based on the principle of self-organization. Innovation ecosystems balance at the "edge of chaos", where the creativity and innovativeness are at the highest level. In such systems, major interventions may fail, while minor changes cause huge outcomes, when the tipping point is being reached and a system moves to another attractor [10, p. 127].

An innovation ecosystem comprises two distinct ecosystems - the knowledge ecosystem and the business ecosystem. The former is driven by research and development, the latter by the market economies. The innovation ecosystem can conceptualize as a complex, interconnected system consisting of three complementary and synergistic sub-ecosystems: science, 


\section{Strategies of effective development of participants the innovative process}

technology, and business ecosystems. Business ecosystem can contain outsourcing partners, technology providers, and complementary product makers. A business ecosystem can be analyzed by extracting information from interviews and desktop research, with a focus on collaboration between key organizations on specific products and services [11].

The main task of strategic development of enterprises in modern conditions is provision the consumer with a special (unique) value, which provides competitive advantages in the market under conditions of trust and commitment of consumers to the offered products and services. As a result, the company becomes an element of the business system, which, due to its network structure, has the opportunity to take into account the interests of its partners as much as possible.

A favourable business environment allows efficiently combine the interests of the company and its partners to determine the relationship of the parties, and thus ways to achieve the goals of development. Best of all, in the current conditions with similar tasks cope with such network structures as clusters. For formation an appropriate institutional environment that integrates individual components of the national innovation system, it is important to create effective networking production systems of innovation orientation. Just the innovation clusters create the conditions for effective innovation cycle from idea generation to obtain economic benefits from innovation. The activities of innovative clusters are aimed at creating of new types of products with long-term competitive advantages.

The role of the environment to support innovation in achieving strategic goals is given in Fig. 2.

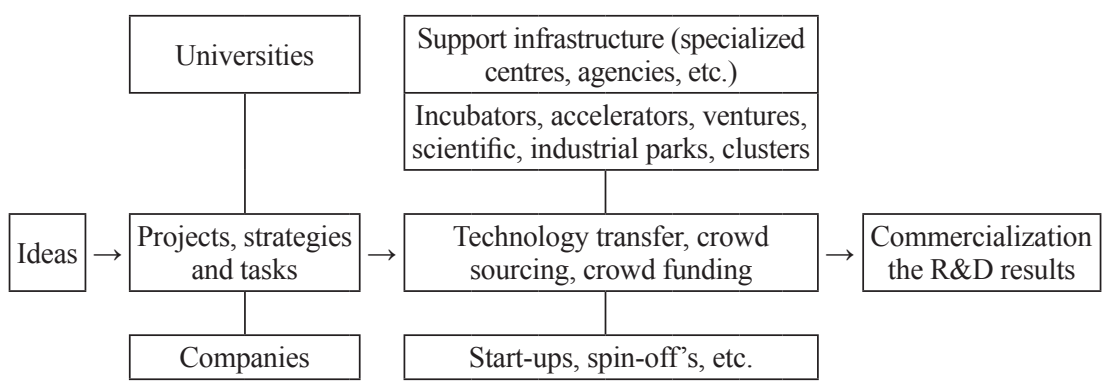

Fig. 2. Environment supporting innovation

Source: Compiled by the author 


\section{Dovbenko Viacheslav}

Under current conditions it imposed higher requirements to expand the circle of persons involved in the innovation process and the formation of new values. Therefore, more and more attention should be directed to open, social and user innovation.

D. Domanski and C. Kaletka argue that the development of a scientific concept of social innovation ecosystems is much more demanding than just trying to adapt concepts such as innovation systems or triple helix to the area of social innovation. This task implies a much better understanding of what social innovation ecosystems are about. One precondition for new ways of developing and diffusing social innovations are necessary (e.g. design thinking, innovation labs etc.) as well as the necessity of a new role of public policy and government for creating suitable environment to the integration of resources of the economy and civil society as well as supporting measures by science and research. Quadruple Helix of social innovation includes as an actors Government, Economy, Academia and Civil Society [12, p. 207-208].

A systemic approach to social innovation focuses on the interfaces of the so far differentiated and largely separate self-referential societal sectors of state, business, civil society and academia, of their corresponding rationalities of action and regulation mechanisms, and at the associated problems and problem-solving capacities. Such collaborations are picked up by at least two different heuristic models, the quadruple helix on the one hand, where government, industry, academia and civil society work together to co-create the future and drive specific structural changes, and the social innovation ecosystem on the other hand, which also asks for interactions between the helix actors, adds the notion of systemic complexity and looks at both, the serendipity and absorptive capacity of a system as a whole. Academic knowledge on social innovation ecosystems is very scarce and the concept is still fuzzy.

Currently, social innovations lack knowledge support, especially from scientific knowledge partners such as universities and research centres. Underpinning the development of social innovations with sufficient expert knowledge and professional models can importantly contribute to a more favourable environment for social innovations. Universities and research centres are not sufficiently integrated in the development of social innovations. In the social innovation ecosystem or quadruple helix they currently still have a minor role, especially when compared with their major role in technological or business innovation [12, p. 227]. 
Questions about transferability and scalability within a given or to another ecosystem dominate social innovation discourses. Scaling in terms of different modes of organisational growth is a typical way. While scaling is a more prominent strategy within a given ecosystem, transfer and adaptive replication more often takes place in a different setting, which helps to reach completely new target groups and goals. Social entrepreneurs, project managers, activists, groups, networks and so on have a motivation to implement a strategy to disseminate their solution for a social problem. In the tab. 3 is given the approaches to implementation of innovative strategy for development and social problems solution.

Table 3

\section{Approaches to implementation of innovative strategy for social problems solution}

\begin{tabular}{|l|l|l|}
\hline \multicolumn{1}{|c|}{ Approach } & \multicolumn{1}{|c|}{ Strategy } & \multicolumn{1}{c|}{ Overview } \\
\hline Replication & Scaling out & $\begin{array}{l}\text { Organisation attempt to replicate their social } \\
\text { innovation in other geographical areas }\end{array}$ \\
\cline { 2 - 3 } & Scaling up & $\begin{array}{l}\text { Organisations attempt to affect a wider } \\
\text { system change by tackling the institutional } \\
\text { causes of a problem }\end{array}$ \\
\cline { 2 - 3 } & Mission networks & $\begin{array}{l}\text { A social entrepreneur rids of traditional } \\
\text { aspects of organisational control (brand, } \\
\text { intellectual property, etc.) to influence and } \\
\text { create other 'change makers' within the } \\
\text { system }\end{array}$ \\
\hline Non-replication & Open Source & $\begin{array}{l}\text { The core intellectual property of the } \\
\text { innovation or organisation is turned into an } \\
\text { open source tool for others to take up }\end{array}$ \\
\hline Mixed & $\begin{array}{l}\text { Other (less explored } \\
\text { potential strategies) }\end{array}$ & $\begin{array}{l}\text { Including: } \\
\text { - Affiliation with new partners } \\
\text { - Direct/indirect dissemination of ideas } \\
\text { - Working to change policy environments } \\
\text { - Social movement building }\end{array}$ \\
\hline
\end{tabular}

Source: Composed by the author on the basis of the paper [12, p. 209]

Innovation management therefore, is a systematic approach to creating an environment based on discovery, invention and commercial exploitation of ideas that meet dissatisfied needs.

Innovation systems involve many actors operating at different stages and scales. Reforming institutions to better align innovation systems with 
sustainable development requires mobilizing collective action across a complex and large set of actors who work at many scales and who engage in activities that overlap and sometimes conflict. The interdependencies of actors may be explicit, such as through technology commercialization licensing agreements that involve a formal contract transferring intellectual property. Alternatively, linkages connecting actors may be implicit, such as the underemphasized dependence of new product development by much computer hardware and pharmaceutical firms on prior government-funded $\mathrm{R} \& \mathrm{D}[13]$.

Need for collective action arise because actors operating across different stages and scales vary widely in their interests and incentives and are not necessarily driven by the goal of sustainable development. For example, a national government usually has little motivation to take into account the needs of citizens beyond its borders, a profit-maximizing firm lacks incentives to invent technologies for people who cannot afford its products, and consumers lack the impetus to consider how their decisions impact to other communities distant in time and space. Therefore, the needs for establishing communication using modern information systems continue to grow.

\section{Mechanism of innovation development}

In order to promote the innovation activity it is important to create an economic mechanism that should provide support and effective regulation of innovation processes in the economy. State support for innovation activities involves a system of measures aimed at stimulating and activating innovation activity. This system includes financial and credit support for the implementation of innovative projects, preferential taxation for innovation actors, support for the functioning and development of modern innovation infrastructure, attraction and encouragement of foreign investments. The formation of innovative model of economic development involves the creation of a favorable legislative field and comprehensive information provision for the participants of innovation process, the formation of state programs of innovation support, raising the level of economic education and innovation culture, reliable protection of intellectual and industrial property rights, improving financing of innovation activity and its tax incentives.

The mechanisms for supporting innovation in the field of science and scientific services in order to obtain the necessary results should be closely linked with similar business mechanisms to ensure the transfer of scien- 


\section{Strategies of effective development of participants the innovative process}

tific outputs to structures that are capable of bringing them to the stage of commercialization. Innovation centers in EU help innovation business in the areas of technology transfer; commercialization of R\&D results; including intellectual property issues; development of adaptation opportunities of companies to new technologies; search of potential partners; implementation of transnational projects. An even more important role in the process of commercialization of innovations plays in particular well-known societies such as Max Plank Gesellschaft, Fraunhofer-Gesellschaft in Germany, the Finnish Innovation Fund SITRA, Finnish Funding Agency for Technology and Innovation and wide range other similar structures in many countries, whose activities are aimed at maintaining the innovation activity of many participants. In general, each country builds its own specific investment model mediation and accumulation of investment in innovation activities, taking into account the specific features of development and situation in the economy.

The system of relationship between participants of the innovation process is formed under the influence of various factors, taking into account the role of a specific subject in the economic process. The most common forms of inter-entity interaction of participants are economic, organizational, logistical, information and legal interaction (Tab. 4).

Table 4

\section{Main types and forms of interaction}

of participants of innovation activity

\begin{tabular}{|l|l|}
\hline \multicolumn{1}{|c|}{ Types of interaction } & \multicolumn{1}{c|}{ Forms of interaction } \\
\hline Economic interaction & $\begin{array}{l}\text { Technological cooperation, coordination of investment } \\
\text { development programs, business planning of innovation } \\
\text { projects }\end{array}$ \\
\hline Organizational interaction & $\begin{array}{l}\text { Association, corporation, innovation centre and park, } \\
\text { innovation cluster, financial and industrial group, } \\
\text { strategic alliance }\end{array}$ \\
\hline Logistic interaction & $\begin{array}{l}\text { Logistics centres, terminal and cargo complexes, } \\
\text { warehouse networks, transport and logistic clusters }\end{array}$ \\
\hline Information interaction & $\begin{array}{l}\text { Network of centres of science and innovations, network } \\
\text { of technology transfer, scientific and resource ICT } \\
\text { centres }\end{array}$ \\
\hline Legal interaction & $\begin{array}{l}\text { Contracts, agreements, regulations, standards, corporate } \\
\text { norms and rules }\end{array}$ \\
\hline
\end{tabular}

Source: Compiled by the author 


\section{Dovbenko Viacheslav}

A firm's overall economic, strategic, and innovation performance is dependent on the degree to which the firm can use all of the knowledge created by the firm and turn this knowledge into value-creating activities. Much of the process and workflow is contained in a mutual understanding of the work or process and it is not easily documented and communicated.

A conceptual model which guides top management at innovative technology companies in the development of intellectual capital should focus corporate resources on the strategic direction and processes needed to increase the intellectual capital of the firm and the delivery of new products to customers. This new intellectual capital would be either patents or trade secrets and would represent a conscious strategy of offensive intellectual capital creation rather than the defensive strategies.

To create a coherent strategy that involves the active use of the relevant capital in the implementation of the innovation strategy is necessary to introduce into the model of innovation development of the company such components [14, p. 318]:

Future Competitive Positioning (FCP)

Product Dynamics

Positioning Dynamics

R\&D Investment

Technology Dynamics

Competitive Dynamics

Environmental Turbulence

Strategy aggressiveness.

The research implications for this model are that changes in an intellectual capital inputs and capabilities can be measured and specific methods related to the most gain for the investment made. A new strategy for knowledge creation would be accompanied by a change in intervening processes using the tacit knowledge measured changes as a proxy for the intellectual capital generated as well as a new set of outputs. The research using this model could be targeted toward technology companies to identify whether the chosen knowledge generation strategy is having the intended effect and what changes need to be made to processes and persons that would yield the desired outputs.

Based on the different possible configurations of business models elements, companies can design different business models to reflect their overall strategic choices. Examples of well-known business model "themes" 


\section{Strategies of effective development of participants the innovative process}

include the "no-frills" model often found in the aviation industry (e.g. Ryanair) or the "customer-lock in" business model of Apple or Nespresso. With the adoption of open innovation practices, "open business models" have emerged as a new design theme [15]. The business-models need to be aligned with the company's overall (innovation) strategy, which implies realign their existing business models to accommodate open innovation practices.

Finally, to effectively harness the potential benefits of open innovation, company need to employ various organizational and managerial practices such as intensive lateral and vertical communication and rewards for knowledge sharing and dedicated incentive systems for innovation, internal research capacity and cross-functional collaboration between departments in the innovation processes as to facilitate accessing and integrating knowledge residing outside the company's boundaries [16].

Open (permission-less) networks are accessible to anyone wishing to join, without restriction on membership. Data stored on these networks is visible to all participants in encrypted format. Digital currency bitcoin is an example. The innovation of blockchain is capable of transforming the infrastructure of our economic systems, not only financial services, where most of the attention is currently concentrated, but entire global value chains and revenue models. It offers a chance to reimaging industries, rebuild financial processes, and build markets once considered improbable or unprofitable [17].

There are also major threats to the application of blockchain. In particular the ability to extraction ("to mining") blockchain is not equal for all, which makes monopoly actions possible. Theoretically, it is believed that selfish miners will tend to unite into pools and thus outperform single miners who will have to join a pool to survive. However the technology of blockchain is dangerous because it can deprive millions of people of jobs, as its implementation will eliminate the need for intermediaries in different areas. But no dangers can stop the implementation of blockchain in most areas of human activity. The blockchain ecosystem is currently in full experimentation mode, bringing new innovations and hybrid solutions. Consortia are emerging globally to discuss and provide solutions, address governance and industry standard issues, and provide regulatory insights. These include The Ethereum Enterprise Alliance and China Ledger, which are attracting participation from dozens of major industry players, innova- 


\section{Dovbenko Viacheslav}

tors, regulators, and governments. The Enterprise Ethereum Alliance connects Fortune 500 enterprises, start-ups, academics, and technology vendors with their experts. The Enterprise Ethereum Alliance (EEA) since February has grown to 200 members.

Collaboration with academic research provides a broader perspective on the potential of a technology. It thus highlights new ways to solve current problems as well as new business opportunities. Research collaboration can help with understanding customer needs better and suggest appropriate directions to seek solutions to technical problems. Innovation is in constant interaction with the customers, suppliers, research institutions and so on. Collaboration also opens direct business opportunities for companies which package and sell academic expertise (consultancies). This also applies to enterprises in which scientists are an important market (instrument manufacturers, computers) and companies for which scientists are key opinion leaders (medical technology) [18, p. 34]. Collaboration provides the opportunity to better combine and exploit the potential of stakeholders interested in developing new products and technologies. The main results of this collaboration are shown in Tab. 5

Table 5

Anticipated results of cooperation with public research

\begin{tabular}{|l|l|l|}
\hline \multirow{2}{*}{ Expected results } & \multicolumn{2}{|c|}{ Area of use } \\
\cline { 2 - 3 } & New innovation opportunities & \multicolumn{1}{|c|}{$\begin{array}{c}\text { Support for current } \\
\text { business areas }\end{array}$} \\
\hline $\begin{array}{l}\text { Directly applicable } \\
\text { results }\end{array}$ & $\begin{array}{l}\text { Commercialisation } \\
\text { of academic research }\end{array}$ & Applied R\&D, problem-solving \\
\hline "Soft" results & $\begin{array}{l}\text { Learning } \\
\text { New perspectives } \\
\text { New business opportunities }\end{array}$ & $\begin{array}{l}\text { Understanding customer needs } \\
\text { Identifying directions for } \\
\text { search }\end{array}$ \\
\hline
\end{tabular}

Source: Composed by the author on the basis of the paper [18, p. 35]

In the state of constant change, companies that are less successful in developing their capability through innovation will fail, while successful companies grow. The interaction between this variety of business experiments and the market's selection of more successful ventures is seen as the main driver of economic renewal.

A great combination for effective innovation is application the combining of Design thinking with Agile. Design Thinking and Agile Methodol- 


\section{Strategies of effective development of participants the innovative process}

ogy are considered two completely different concepts, with the two being viewed as separate and independent of each other. Agile is primarily about the how of a project, with planning done in chunks rather than as a whole; scope of work is usually variable with Agile, while time and quality are fixed. Design thinking on the other hand, is about exploring and generating ideas, understanding users and innovating to meet customer needs [19].

Design Thinking has been central to modern innovations in various fields, from the arts to sciences and engineering and even in business. It has also been a staple of leading brands like GE, IBM and Samsung and the world's top schools like Stanford's school, MIT, and Harvard have integrated Design Thinking into their curriculums. Similarly, Agile has been around for a while, with its own language and methodologies and is widely used in the IT industry. Derivative of the Agile is Scrum that follows the same iterative process. It is an effective, smart and perfect example of how maximum input equals maximum output. And so we see the while design thinking helps us understand what work to do, Scrum gives us vision to decide how to do it. More productive and faster product and service innovation can be achieved combining Agile and Scrum with Stage-Gate. Examples of early adopters of this new system are appearing around the world.

Business model choice determines the nature of complementarity between business models and technology and the paths to monetization. A long-standing distinction between "project based offerings" and "pre-designed (scale) based offerings" often described as the "taxi' and "bus" systems is useful in this context. Organizations such as consulting firms and movie makers use the taxi system to create value, while organizations such as automobile assemblers and providers of fast food utilize the bus system and add value by producing "one-size-fits-all" goods or services in a repetitive manner from a standardized format [20, p. 422]. Examples of the Business-models for companies in several areas are given in Tab. 6.

Making business model choice a moderator, and including the factors that influence business model change in a dynamic manner, will lead to a better understanding of the fundamentals of the relationship. And it will also allow strategists to comment more succinctly and usefully on key contingencies - such as, why so many innovative products fail; how successful firms conceive the relationship between technology and business model; and how they conceive the dynamics of the process of business model adjustment. Making business model choice a moderator, and including the 
Table 6

Examples of the Business Models

\begin{tabular}{|c|c|c|c|c|c|}
\hline & $\begin{array}{c}\text { Fast food } \\
\text { chain - } \\
\text { franchised } \\
\text { BM }\end{array}$ & $\begin{array}{c}\text { Boutique } \\
\text { strategy } \\
\text { consultant } \\
\text { BM }\end{array}$ & $\begin{array}{c}\text { Military } \\
\text { contractor } \\
\text { BM }\end{array}$ & $\begin{array}{l}\text { Newspaper } \\
\text { (1990s) BM }\end{array}$ & $\begin{array}{c}\text { Searching } \\
\text { system BM }\end{array}$ \\
\hline \begin{tabular}{|l}
\multicolumn{1}{c}{ Customer } \\
identification \\
Are users \\
paying, if \\
not who are \\
the other \\
customers
\end{tabular} & $\begin{array}{l}\text { Simple BM } \\
\text { User pays the } \\
\text { intermediary } \\
\text { franchise }\end{array}$ & $\begin{array}{l}\text { Simple } B M \\
\text { User pays }\end{array}$ & $\begin{array}{l}\text { Simple BM } \\
\text { User is } \\
\text { typically the } \\
\text { government } \\
\text { who pays }\end{array}$ & $\begin{array}{l}\text { Hybrid BM } \\
\text { Readers pay } \\
\text { per copy } \\
\text { Advertisers } \\
\text { give bulk of } \\
\text { revenues }\end{array}$ & $\begin{array}{l}\text { Hybrid } B M \\
\text { Free for } \\
\text { users, but } \\
\text { advertisers } \\
\text { pay }\end{array}$ \\
\hline $\begin{array}{l}\text { Customer } \\
\text { engagement } \\
\text { "Taxi" or } \\
\text { "Bus" }\end{array}$ & $\begin{array}{c}\text { Bus } \\
\text { Scale based }\end{array}$ & $\begin{array}{l}\quad \text { Taxi } \\
\text { Projects to } \\
\text { order }\end{array}$ & $\begin{array}{l}\text { Taxi } \\
\text { Usually } \\
\text { project based }\end{array}$ & \begin{tabular}{l}
\multicolumn{1}{c}{ Bus } \\
Readers and \\
advertisers \\
are given bus \\
service
\end{tabular} & \begin{tabular}{|l} 
Bus for \\
users \\
Taxi for \\
advertisers
\end{tabular} \\
\hline \begin{tabular}{l}
\multicolumn{1}{|c}{ Value chain } \\
$\quad$ links \\
Integrated, \\
hierarchy or \\
network
\end{tabular} & $\begin{array}{l}\text { Highly tiered } \\
\text { system of } \\
\text { suppliers and } \\
\text { franchisees, } \\
\text { who are linked } \\
\text { hierarchically }\end{array}$ & $\begin{array}{l}\text { Almost all } \\
\text { value is } \\
\text { delivered by } \\
\text { the firm, little } \\
\text { outsourcing }\end{array}$ & $\begin{array}{l}\text { Complex } \\
\text { system of } \\
\text { arrangements } \\
\text { among many } \\
\text { partners }\end{array}$ & $\begin{array}{l}\text { Content and } \\
\text { production } \\
\text { are } \\
\text { hierarchical } \\
\text { but at times } \\
\text { network } \\
\end{array}$ & \begin{tabular}{|l|} 
Complex \\
tightly \\
controlled \\
links \\
orchestrated \\
by firm \\
\end{tabular} \\
\hline $\begin{array}{l}\text { Monetization } \\
\text { When, What } \\
\text { and How is } \\
\text { money raised }\end{array}$ & $\begin{array}{l}\text { Complementary } \\
\quad \text { assets } \\
\text { Franchisee } \\
\text { collects money } \\
\text { from consumer } \\
\text { and passes on } \\
\text { fee }\end{array}$ & \begin{tabular}{l}
\multicolumn{1}{c}{ Value } \\
Often priced \\
on the basis \\
of fee plus \\
share of the \\
value created
\end{tabular} & \begin{tabular}{l}
\multicolumn{1}{c}{ Cost } \\
Staged \\
payments \\
and often \\
cost plus \\
contract
\end{tabular} & \begin{tabular}{l}
\multicolumn{1}{c}{ Two-sided } \\
Everyone \\
pays close to \\
point of use
\end{tabular} & $\begin{array}{l}\text { Two-sided } \\
\text { Advertisers } \\
\text { pay after } \\
\text { service is } \\
\text { delivered }\end{array}$ \\
\hline
\end{tabular}

Source: Composed by the author on the basis of the paper [20, p. 421]

factors that influence business model change in a dynamic manner, will lead to a better understanding between participants of innovation process.

Open innovation does not mean that companies refuse their own R\&D development, but is a way to effectively access external knowledge and their target use. In order to enhance the synergy effect of the transfer of knowledge and technologies in Ukraine, it is important to make a sharp shift to the needs of science and education, which should foresee obtaining a given area of its corresponding status, and thus financing not only its current, but also perspective needs. But for this purpose, it is necessary to create a new 
mechanism for supporting $R \& D$ on the principles of open innovation with the involvement of business structures. The individual components and features of this mechanism are given in the Tab 7.

To achieve the optimal combination of elements supporting mechanism for implementation the results of $\mathrm{R} \& \mathrm{D}$, it is important to create a modern innovation infrastructure that will promote the process of ideas generation and timely attention to the questions of realization the most promising innovative projects. For the results of perspective scientific research commercialization through the technology transfer of industrial and intellectual property may be created favourable conditions.

Table 7

\section{Components and features of the $R \& D$ mechanism support}

\begin{tabular}{|c|c|c|c|c|}
\hline $\begin{array}{l}\text { Participants } \\
\text { of transfer }\end{array}$ & $\begin{array}{c}\text { Innovation } \\
\text { transfer } \\
\text { infrastructure }\end{array}$ & $\begin{array}{l}\text { Main kinds } \\
\text { of transfer }\end{array}$ & $\begin{array}{l}\text { Opportunities } \\
\text { and results } \\
\text { of transfer }\end{array}$ & $\begin{array}{c}\text { Transfer } \\
\text { effectiveness }\end{array}$ \\
\hline \multirow{2}{*}{ Science } & $\begin{array}{l}\text { Universities, } \\
\text { research firms }\end{array}$ & \multirow{2}{*}{$\begin{array}{l}\text { Transfer of } \\
\text { knowledge and } \\
\text { innovation }\end{array}$} & \multirow{2}{*}{$\begin{array}{l}\text { Getting new } \\
\text { knowledge, } \\
\text { skills and } \\
\text { abilities }\end{array}$} & \multirow{10}{*}{$\begin{array}{l}\text { Identification } \\
\text { of the future } \\
\text { market needs. } \\
\text { Offers new } \\
\text { developments, } \\
\text { products and } \\
\text { technologies. } \\
\text { Formation } \\
\text { of balanced } \\
\text { innovative } \\
\text { ecosystems, } \\
\text { providing } \\
\text { synergy effect } \\
\text { on effective } \\
\text { interaction of } \\
\text { participants }\end{array}$} \\
\hline & $\begin{array}{l}\text { Scientific and } \\
\text { technological parks }\end{array}$ & & & \\
\hline \multirow{4}{*}{ Business } & Business-angels & \multirow{4}{*}{$\begin{array}{l}\text { Technology } \\
\text { transfer }\end{array}$} & \multirow{4}{*}{$\begin{array}{l}\text { Purchase/selling } \\
\text { of patents, } \\
\text { licenses, } \\
\text { equipment, } \\
\text { scientists and } \\
\text { specialists }\end{array}$} & \\
\hline & Business-incubators & & & \\
\hline & Venture companies & & & \\
\hline & $\begin{array}{l}\text { Technology transfer } \\
\text { centres }\end{array}$ & & & \\
\hline \multirow{2}{*}{ State } & Innovations clusters & \multirow{2}{*}{$\begin{array}{l}\text { Financial } \\
\text { transfers }\end{array}$} & \multirow{2}{*}{$\begin{array}{l}\text { New knowledge } \\
\text { and technologies } \\
\text { use }\end{array}$} & \\
\hline & Technopolises & & & \\
\hline \multirow[b]{2}{*}{ Society } & Customers & \multirow{2}{*}{$\begin{array}{l}\text { Crowdsourcing, } \\
\text { crowdfunding }\end{array}$} & \multirow{2}{*}{$\begin{array}{l}\text { Participation } \\
\text { in surveys and } \\
\text { contests }\end{array}$} & \\
\hline & $\begin{array}{l}\text { Inventors, } \\
\text { rationalisers }\end{array}$ & & & \\
\hline
\end{tabular}

Source: Compiled by the author

For this purpose, it is necessary significantly increase the role of the state in implementing economic transformations based on innovations and ensure active participation of each active member of society in the innovation process in the most suitable role for him (innovator, expert, mentor, investor, student, etc.). Such approach will provide a combination of 
interests of the parties and create the necessary conditions for reducing the innovation cycle and enable significantly strengthen the role of innovative component in the economic development.

\section{Conclusions}

Innovations promise often far-reaching changes that can affect the company's business model. An innovation process is absolutely essential to eliminate errors and unnecessary loops due to missing or incorrect information and also to ensure efficiency and productivity.

However, this can not be achieved without due attention to innovation, which, unfortunately, is alien to the overwhelming majority of domestic enterprises, whose activities are primarily related to the survival or work on the basis of the use of outdated and worn-out of $60-90 \%$ equipment. To succeed in economic transformations, management approaches at all levels need to be changed. It should be combined with efforts aimed at saving and efficient use of all resources and implement the transformation of economic and social relations based on the priority of solving various tasks to address glaring disparities in development of different sectors of the economy. For this it is important to achieve a significant enhancement the productivity of labour and through this provide increased levels of loans and increase of its attraction, which requires the necessary level of trust the involved parties. It is necessary to ensure at least twice increase the level of expenditure for science in GDP, establish a privileged tax regime for innovation activity and promote investment in innovative projects and commercialization of $R \& D$ results.

Innovation strategy is significantly affected by innovation potential and management, lateral thinking, innovation, investment climate and organizational structure. Currently for increasing the innovation activity faithfully is set-up of cooperation among different partners involved in innovation process. For this purpose best suited the open innovation strategy which implies greater use of common know-how and resources. Innovation strategy will require a change of organizational structure of the company and raising the level of motivation of employers.

The process of implementation the innovation strategy is highly dependent from quality of innovation ecosystem, which includes the innovation infrastructure, legislative field, level of state support of innovation, investment climate and trust between different parties. Innovation ecosystem is viewed then as a dynamic system, characterized by localized interac- 


\section{Strategies of effective development of participants the innovative process}

tions among a huge amount and diversity of agents - universities, business enterprises, public institutions, society, resources, etc. The lack of existing innovation ecosystem lays in underestimation of role the social innovation. Encourage of social innovations can importantly contribute to a more favourable environment for effective interaction of participants in the innovation process in order to improve the quality of the generated ideas and solutions for their further incarnation. For successful implementation of strategies for the effective development of innovation structures, it is important to establish and properly apply the mechanism for supporting the activities of all parties involved in the innovation process. For achieving the best results in the process of commercialization of $R \& D$ results it is important to use the best foreign experience in the field of innovation, which includes the creation of a modern innovation infrastructure based on science parks, innovative clusters and centres of knowledge and technology transfer. In case of proper selection of the individual components of the mechanism of innovation development and creation the conditions for optimal interaction of all parties, a synergy effect will be obtained that will ensure a more efficient use of the resource potential and allow for an additional cumulative effect manifestation.

In further research will be develop the questions of maintaining the innovation activity in order to enhancing the collaboration native and foreign participants of innovation structures in order to establish a mutually beneficial exchange of experience and ensure the productive use of innovative infrastructure objects.

\section{References:}

1. Innovative Ukraine 2020: National Report / per co. edit. V.M. Geits and others; National Academy of Sciences of Ukraine. - K., 2015. - 336 pp.

2. Fedulova L. Business Models of Innovative Development of Trade Enterprises / L. Fedulova. KNTEU Bulletin. 2017. No. 3. - P. 48-64.

3. Lendel V. Creation and implementation of the innovation strategy in the enterprise / Viliam Lendel, Michal Varmus / Economics and management: 2011. \#16. - P. 819-825.

4. Enterprise Potential Management. Teaching manual / I.Z. Dolzhansky, T.O. Zagornaya, O.O. Udalych. - K.: Center for Educational Literature, 2006. $362 \mathrm{pp}$.

5. Zakharkin O., Zakharkina L. (2014) Substantiation of the enterprise innovation development strategy and its aims. Ekonomichnyi chasopys (Economic Annals-XXI), 7-8. - P. 76-79. (in Eng.). 


\section{Dovbenko Viacheslav}

6. Illiashenko S. M. Knowledge management as a basis for company's innovative development / S. M. Illiashenko, Y. S. Shipulina, N.S. Illiashenko, Actual problems of economics \#6 (168), 2015. - P. 173-181.

7. Chesbrough H. Open innovation and strategy. / H. Chesbrough, M. Appleyard. California Management Review. 2007, vol. 50, no. 1. - P. 57-74.

8. Jemala M. Introduction to open technology innovation strategies /Marek Jemala. Acta Oeconomica Pragensia. 2010. \#18(3). - P. 3-20.

9. Building Knowledge Economy through Innovation Ecosystem: The Role of Innovation Hubs / Brussels, 2014. - 46 pp. Retrieved from: https:// www.knowledge-economy.net/uploads/documents/2014/KEN-2014\%20Analytical\% 20Compendium.pdf

10. Jucevičius G. Smart development of innovation ecosystem / G. Jucevičius, K. Grumadaite. Procedia - Social and Behavioral Sciences 156 (2014). P. 125-129.

11. $\mathrm{Xu}, \mathrm{G}$. Exploring innovation ecosystems across science, technology, and business: A case of 3D printing in China / G. Xu, Y. Wub, T. Minshallc, Y. Zhou // Technological Forecasting \& Social Change. 2017. Retrieved from: http://dx.doi.org/10.1016/j.techfore.2017.06.030 - 14 pp.

12. Atlas of social Innovation: New practices for a better future / edited by J. Howaldt, Ch. Kaletka, A. Schröder, M. Zirngiebl. Technische Universität Dortmund, ZWE Socialforschungstelle. 2018. - 245 pp.

13. Anadon L.D. Making technological innovation work for sustainable development /L.D. Anadon, G. Chan, A.G. Harley, K. Matus, S. Moon etc. PNAS, 2016. August, 113 (35) p. 9682-9690.

14. Harlow H. Strategically Developing Intellectual Capital Effectiveness: A Conceptual Model for Innovative Companies / Harold Harlow. Electronic Journal of Knowledge Management Volume 11 Issue 4, 2013. - P. 309-324.

15. Chesbrough H.W. Open Innovation: The New Imperative for Creating and Profiting from Technology / H.W. Chesbrough. Harvard Business Press, 2006. 227 pp.

16. Saebi T. Business models for open innovation: matching heterogonous open innovation strategies with business-models dimensions / T. Saebi, N.J. Foss. Retrieved from: https://brage.bibsys.no/xmlui/bitsteam/id/360089/Saebi_Business.pdf

17. Blockchain in Development - Part I: A New Mechanism of 'Trust'? / EMCompass: Fresh Ideas about Business in emerging Markets. International Finance Corporation Bulletin. July 2017. N. 40. Retrieved from: http://www.ifc.org/ ThoughtLeadership

18. Lennart E. Innovations and new technology - what is the role of research? Implications for public policy/E. Lennart. VINNOVA Analysis VA. 2014. - 64 pp.

19. Design thinking + Agile: A great combination for effective innovation. Innovation. 16 januar 2017. Retrieved from: https://www.corporate-alchemists. com/design-thinking-agile-innovation/

20. Baden-Fuller C. Business Models and Technological Innovation / C. BadenFuller Stefan, S. Haefliger. Long Range Planning. Volume 46, Issue 6, December 2013. - P. 419-426. 